Shimizu, Tomohisa. 1971. Native Americans [in Japanese]. Tokyo: Chuko-Shinsho. Uchimura, Kanzo. 1913. “Downfall of America.” Yorozu Choho, May 8.

Uesugi, Shinkichi. 1924. Nichibei Shototsu no Hisshi to sono Kakugo [Coming War with America]. Tokyo: Dainihon Yubenkai.

Yosino, Sakuzo. 1918. "Beikoku Kouza Shinsetsu ni taisuru Bunsho Kansho no Fusetsu" ["Rumors about Interference of the Minister of Education on Establishment of the American Lecture Series"]. Chuo Koron 33 (6): 109.

\section{A LESSON IN EVENTFUL TEMPORALITY: PEDAGOGIES OF DONALD TRUMP FROM ABROAD}

\section{Thomas Jessen Adams, University of Sydney, Australia}

\section{DOI: $10.1017 / S_{1049096519002002}$}

An unexpected consequence of Donald Trump's presidency has been its occurrence exposing popular simplifications of American history and politics. Trump's election and presidency has had the salutary effect of sharpening some of the contradictions of American political analysis. Methodological orientations, epistemologies, and just-so thinking that were taken for granted-in scholarship and in popular thought-have been exposed for their deep decontextualization and simplification.

I began teaching US history and politics in Australia in 2014 after 10 years in diverse American university contexts. Beyond important institutional contrasts, the key difference between American and Australian students is native contextual knowledge. This, of course, is standard for anyone teaching geographically contingent topics outside of the subject country. ${ }^{1}$ We cannot assume that students have some knowledge of things we often take as given when walking into an American classroom. Things as diverse as rights-based constitutionalism and basic geographic characteristics cannot be assumed. American federalism and local governance are often particularly alien. For instance, a lecture on the politics and history of school segregation must attend to foreign notions of municipal control of education. Students also are less embedded in ongoing ideological debates within American culture-especially social media-about the meaning of Trump. Finally, whereas Australian students occasionally exhibit stereotypes of the United States and Americans, in most instances, they are so self-evidently shallow (e.g., all Americans own guns) as to be easily disabused and, in my experience, less ingrained than stereotypes of Americans vis-à-vis other Americans.

These contexts precede the manner in which students and the broader public at large in Australia understand American political life. The scale of global surprise that greeted Trump's election rivaled that of most Americans. Indeed, given that outlets like the New York Times and fivethirtyeight.com probably disproportionately inform the opinions of non-Americans and local media outside of the United States, it is quite possible the disbelief surpassed that experienced in American living rooms on November 8, 2016. I spent much of that night doing interviews with Australian media, the subject of which was some variation of "How could (most) everyone have gotten this so wrong?"

Continued surprise also has been the hallmark of how Trump appears in my classroom. His presidency is an event that requires explanation-for students, the general public, and scholars alike. An event that many were unable to conceive of before the fact and are baffled by after the fact. I emphasize event because sophisticated thinking about events, what Sewell (2005) termed "eventful temporality," is a hallmark of theoretically conscious historical epistemology and what separates it from its positivistic/experimental and teleological/path-dependent social-scientific cousins. Eventful temporality disavows the notion intrinsic to experimental/ positivistic social science that causality and its measurement can be fixed across time and place and that any occurrence can be isolated from its context. Although I agree with teleology/path dependency insofar as arguing that prior events affect those in the future, eventful temporality denies that causality and its structures can be uniform across time and space (Sewell 2005). This framework is not limited to the discipline of history but rather is found across divisions of human knowledge. It is an epistemological point, not a disciplinary one-a point that Trump's presidency usefully demonstrates in the classroom.

When students bring less fixed knowledge of American life to the classroom, it is precisely the unfathomability of Trump that makes him pedagogically useful. The broad popular explanations for Trump's election typically involve some prioritization of one of the following abstractions: so-called racial resentment; sexism and misogyny; populism defined as mood/status anxiety (Jäger 2019)2; anti-Muslim/Latin American nativism; non-voting; James Comey's actions; Russian interference; third-party voting; supposed white working-class conservatism; the reemergence of Theodor Adorno's authoritarian personality; voter suppression; deindustrialization, or automation and capital flight. Through encounters with scholarship or media, students bring these explanations into the classroom. Unembedded in ongoing popular debates within American life, however, they are less ideologically wedded to specific explanations for Trump.

This is not to advance or critique any of the previous interpretations but rather to suggest that each as an explanation for an event like Trump's election/presidency begs more questions than they answer. This opens up a broad pedagogical space to study a wide swath of radically different temporal events in American political life-from centuries of American exceptionalist ideology to the forces behind deindustrialization; from the strategies of modern voter suppression to the broad diversity of reasons more Americans see no reason to vote than vote for any single candidate. Accounting for the existence of one of these interpretations requires a contingent and temporally heterogeneous explanation. Accounting for the event of Trump's presidency in any halfway convincing manner then requires a sophisticated attention to countless other events and processes of radically distinct temporalities.

Less embedded in American popular and social media discourse, Australian students grasp this intuitively. To understand the existence of something like "racial resentment" as a motivating factor for a political decision, they then immediately want to know when, why, in what context, and for whom does this catch-all concept become motivating? In student discussion, I have rarely seen recourse to the phenomenon as pathologicalfor instance, built into American cultural "DNA"-that often becomes the explanation in US contexts. Rather, which policies, cultural trends, or political strategies led a certain group to act on this in this specific time and place? If some cohorts of Americans tend to exhibit characteristics of "racial resentment" or nativism, why do some act on it in politically meaningful ways and others do not? Why do some people exhibit these characteristics one day in the voting booth and show solidarity in the workplace the next? The very existence of so many distinct interpretive strands for this singular event and the clear way in which these strands are themselves temporally eventful tends to disabuse students of the more monocausal explanations such as Comey's actions. Students quickly 
default to a preference for overdetermination in the face of just-so narratives, ranging from Russian interference to the almost neurological existence of something like an authoritarian personality.

As an epistemological strategy, the beneficence of temporal eventfulness is most clear in relationship to recognizably big events. An explanation for those events built on radically heterogeneous temporalities clearly "trumps" those that imagine path dependency or positivist certainty as meaningful explanations for social phenomena when the stakes are raised. Such a standpoint can filter down to events that are less prima facie world historic. Why imagine that an event like Trump's election functions any different than any other event? In this way, the global surprise that greeted Trump's rise provides an object lesson in eventful temporality, a pedagogical "silver lining" for those of us trying to help students across the globe make compelling interpretations of their world.

\section{NOTES}

1. For an exploration of this in relationship to broader intellectual and research culture, see Adams and Gleeson-White (2018).

2. For an excellent recent discussion of history of "populism" as a term and its relationship to status anxiety and Cold War social science, see Jäger (2019).

\section{REFEREN CES}

Adams, Thomas Jessen, and Sarah Gleeson-White. 2018. "American Cultures: The View from the Pacific." Journal of American Studies 52 (3): 589-92.

Jäger, Anton. 2019. "The Masses Against the Classes, or, How to Talk About Populism Without Talking About Class." Nonsite.Org 28 (May).

Sewell, William H., Jr. 2005. Logics of History: Social Theory and Social Transformation. Chicago: University of Chicago Press, 100

\section{TEACHING TRUMP'S "AMERICA FIRST" IN/FROM BEIRUT}

\section{Karim Makdisi, American University of Beirut, Lebanon}

\section{DOI: $10.1017 / S_{1049096519001963}$}

Viewed from Beirut, US policy toward the Middle East under the Trump presidency, as of late summer 2019, appears to be largely incoherent and unpredictable, reflecting Trump's volatile nature and personalization of policy. It also reflects his (and his inner circle's) deep ignorance of the region. For example, one day he vows to keep US troops in Syria to ensure ISIS's destruction and combat Iranian influence; the next day, after a telephone call with the Turkish president, he tweets his intention to completely withdraw all US troops-apparently without consulting his generals-imperiling local allies such as Kurdish forces in northeastern Syria. Trump threatened to "obliterate" Iran and ordered a military strike, only to halt it (apparently on the advice of Fox News presenter Tucker Carlson) and call for negotiations without preconditions. Similarly, Trump's support for Saudi Arabia and the United Arab Emirates' siege of Qatar-home to the largest US military base in the region-simply could not have been predicted. Neither could his tacit approval of Saudi Arabia's dramatic forced detention of and alleged physical assault on Lebanon's prime minister.

At the same time, US regional Middle East policy under Trump appears from Beirut to be conspicuously consistent, organized around unwavering support for a narrow far-right-wing Israeli agenda. This consistency reflects both his inner circle's individual ideological positions-particularly his son-in-law Jared Kushner, who is "unabashedly pro-Israel" (Rothkoph 2019) - and the influence of his evangelical popular base (Borger 2019). His so-called Deal of the Century to end the Arab-Israeli conflict is based unabashedly on legitimizing Israel's control over occupied land and ensuring Palestinian submission to unilateral Israeli demands. This approach abandons his predecessors' (nominal) references to liberal "values," international law, and long-standing US policies (e.g., supporting a two-state solution and recognizing Syrian sovereignty over occupied Golan). Trump's regional strategy thus far prioritizes the consolidation by any means necessary of Israel's hegemonic regional position in the face of a perceived IranianHezbollah threat. Reversing Barak Obama's strategy, Trump rebuilt ties with an increasingly militaristic Saudi Arabia, unilaterally withdrew the United States from the Iran nuclear deal, and imposed a "maximum-pressure" policy on Iran (and Hezbollah) with unprecedented US economic sanctions and threat of military action.

In light of this, is there anything new in teaching US foreign policy in the age of Trump, from the vantage point of Beirut? No and yes.

No, because historicizing US-Middle Eastern relations has always been central to the classroom experience. This is in contrast to many political science courses in the United States that view history as a prop to be "engaged with at the 30,00o-foot level" (Musgrave 2019). From Beirut, it is self-evident that the US Middle East strategy is marked structurally more by continuity than rupture on such issues as unqualified US support for Israel, protecting oil resources and client monarchies in the Gulf, consolidating military bases throughout the region, and fighting "terrorism." There also is continuity in classroom investigations theorizing the diminishing US influence both within an international liberal order in crisis and, more specifically, in the Middle East, particularly following the catastrophic 2003 Iraq War-a war that continues to loom large and shape the regional order even after the 2010 Arab uprisings (Makdisi 2017).

History, moreover, is something students and teachers in the region are continuously living, experiencing, and practicing. This has not changed in the age of Trump. We regularly interact in and beyond the classroom-either directly or structurally within clear power discrepancies-with people who experience insecurity but whose agency is denied in mainstream political science literature. The challenge in the classroom is how to make sense of these interactions. My colleagues and I have argued that even before Trump's election, teaching from Beirut (as in other parts of the Global South) "requires recognition of how others experience insecurity." We have sought to encourage approaches and class discussions on "local understandings of insecurity that recognize the destabilizing impact of recent US policy, and in which local actors might play a meaningful role in shaping practices of global governance" (Hazbun, Makdisi, and Pison-Hindawi 2019). So, the idea is not only to assess US action and policy in the classroom (or in our research) or to question the extent of scholar activism needed (as perhaps is the case in more progressive US classrooms) but rather to think meaningfully in both theoretical and empirical terms about local agency (without being parochial).

Despite this sense of strategy or policy continuity and contemporary relevance of both history and the lived experience of students, teaching Trump's US politics from Beirut also feels different-even new-albeit in ways that admittedly are still difficult to pin down.

The uniquely personalized nature of Trump's rule, seemingly free of party or ideological restrictions, makes us examine even more closely the individual/personality level in the classroom. This is difficult to teach systematically because it appears to be shorn of context. 